\title{
Paideusis
}

\section{Philosophical Issues in Education (Cornel Hamm)}

\section{Richard Barrett}

Volume 5, Number 2, 1992

URI: https://id.erudit.org/iderudit/1073352ar

DOI: https://doi.org/10.7202/1073352ar

See table of contents

Publisher(s)

Canadian Philosophy of Education Society

ISSN

0838-4517 (print)

1916-0348 (digital)

Explore this journal

Cite this review

Barrett, R. (1992). Review of [Philosophical Issues in Education (Cornel

Hamm)]. Paideusis, 5(2), 46-47. https://doi.org/10.7202/1073352ar

(C) Richard Barrett, 1992

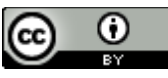

This document is protected by copyright law. Use of the services of Erudit (including reproduction) is subject to its terms and conditions, which can be viewed online.

https://apropos.erudit.org/en/users/policy-on-use/
This article is disseminated and preserved by Érudit.

Érudit is a non-profit inter-university consortium of the Université de Montréal, Université Laval, and the Université du Québec à Montréal. Its mission is to promote and disseminate research.

https://www.erudit.org/en/ 


\section{Cornel Hamm, Philosophical Issues in Education (London, New York and Philadelphia: Falmer Press, 1989)}

This book is intended as a text for persons beginning the discipline of philosophy or education and assumes no prior knowledge of philosophy or of education. The author claims that the book exhibits three great virtues-clarity, completeness and currency-which distinguish it from other texts and which make it more accessible than, in particular, The Logic of Education by Hirst and Peters (London: Routledge and Kegan Paul, 1970).

This review comments, firstly, on the virtues the author claims for the work and, secondly, on other features of interest.

The first virtue, clarity, that Hamm strives for is the simple and clear expression of ideas without the sacrifice of rigour. This is attempted mainly through the use of plain language. It is, in my judgment, very poorly executed. There are hundreds of instances of stylistic infelicity in the text; it is no pleasure to read, and does not improve by being read aloud. The aim of writing in order to be understood ought not to be different from the aim of writing well, and the production of such an ineptly crafted work should, perhaps, be taken as an indictment on the whole idea of writing at the presumed level of the reader's comprehension.

The other two virtues are more successfully enacted. The comprehensiveness of this volume in covering the nature and justification of education, the ways of philosophy as an analytical method, and the social and moral aspects of education is as inclusive as could reasonably be expected of an introductory volume. Further, the currency of the work, is, to my knowledge, without match in all the literature in philosophy of education.

The book starts with two very good chapters. These deal with the nature of philosophical inquiry into education, and with metaphor in educational discourse. The first includes an enunciation of three crucial questions: What do you mean? How do you know? and What is presupposed? It also treats the nature of definitions. This is all done in a way which convinces one that such analysis has a point to it. It is, however, strange that the three questions are not a prominent presence as headings in the rest of book which lacks the incisiveness that the use of such organization would promote. Similarly, the material on metaphors is very instructive about the vagaries of the words we use, but has no following in the later chapters.

After a good introduction to the methods and purpose of philosophy of education, the work continues in the third, fourth, and fifth chapters with treatments of the aims and content of education. This is all very bland to a reader familiar with the topics, but is perhaps a useful introduction for the novice. It can also be observed that a welcome feature of the book is the inclusion of questions and exercises at the end of each chapter.

There then follow chapters on child-centred curricula and teaching and leaming. The rather brief treatment of the issues is compensated for by some good questions at the end of the sections for students to work on. The chapter on interpersonal and social issues in education covers the topics of punishment and authority in an entirely familiar way, and then ends with a very stimulating introduction to the matter of the student-teacher relationship; this is disappointingly left in the air, since none of the questions at the end of the chapter touch upon it. 
The ninth chapter on moral education promises to be the most important. It is not only the longest chapter by far, but it concerns a topic on which Hamm has published more original material than on all other topics combined. The discussion of developmentalism and values clarification is unsatisfying for being too brief and congested; the latter approach is dismissed for a long list of reasons all bunched into one paragraph, mostly into one sentence (p. 138), and would mean little to a student new to the subject, even if it were readable. A strong feature of the chapter, however, is a careful elucidation of the multiplicity of values; and a few pages of charts are helpful towards this. Then, Hamm's views on the proper model for moral education are offered. Morality is defined as doing the (morally) right things for the right reasons. And, after some familiar objections to the teaching of moral content have been repudiated, the way is clear for a methodology for the achievement of virtue. The methodology includes exemplification, encouragement, and enlightenment in moral concepts, principles, and reasoning. This position is strikingly positive; it will probably provoke more enthusiastic discussion among students than any other section of the book.

To conclude, the strength of this text are the treatment of philosophical analysis, definitions, and metaphors; the presentation of interesting thoughts on moral education; and the provision of questions and exercises on each topic. It is unfortunate that the book does not manifest the clarity of expression that is posited as its main merit. As for the other virtues claimed for it, I suggested that, at least for an introductory text, the work is comprehensive and current enough. I would not be surprised, however, if others might suspect that there is something peculiar about claiming, on the one hand, that a book is essentially a simpler rendering of the ideas put out by Hirst and Peters twenty years ago and, on the other, that it is comprehensive and current. For that seems to suggest that analytical philosophy of education has, over two decades, argued the details of seminal work without extending itself to encompass any new topics.

Reviewed by Richard Barrett, Elmira College, New York 